\title{
Cohesion and news translation
}

\section{An exploratory study of shifts of cohesion in the Hungarian-English translation of news stories}

\author{
Krisztina Károly \\ School of English and American Studies, Eötvös \\ Loránd University, Budapest \\ karoly.krisztina@btk.elte.hu
}

\section{Szilvia Kovalik Deák}

Doctoral School of Linguistics, Eötvös Loránd University, Budapest

kovalik@t-online.hu

\author{
Andrea Éva Mészáros \\ Doctoral School of Linguistics, Eötvös Loránd \\ University, Budapest \\ andrea.meszaros@gmail.com
}

\author{
Henrietta Ábrányi \\ Doctoral School of Linguistics, Eötvös Loránd \\ University, Budapest \\ heni.abranyi@t-online.hu
}

\section{Ágnes Laszkács}

Doctoral School of Linguistics, Eötvös Loránd University, Budapest

laszkacs.agnes@chello.hu

\section{Márta Seresi}

Doctoral School of Linguistics, Eötvös Loránd University, Budapest

seresi.marta@freemail.hu

Abstract: This study explores the (re)creation of cohesion in the English translations of Hungarian news stories. It reveals the quantity and quality of shifts of cohesion and the extent to which these are influenced by the differences between the languages, the stereotypical features of the kind of translation (news translation) and the genre (news story). Results indicate no significant quantitative shifts in translation; the in-depth analysis of the corpus, on the other hand, shows considerable qualitative shifts, some of which (optional shifts in particular) modify news contents. The paper also investigates the validity of the explicitation and the repetition avoidance hypotheses regarded as universals of translation.

Keywords: cohesion, shifts, news translation, news story, event structure

\section{Introduction}

Our globalized world and the requirements of the information society place the media and within that news translation in the limelight and put special constraints on the work of the translator. The critical examination of news as discourse has been in the focus of attention over the last 30 years (for an overview see Holland 2006, 230), and a similar increase of interest may be observed in the study of translating news discourse. Research shows 
differences in the degree to which the translations of news stories depend on their sources: some translations completely alter the contents of their sources, producing "significantly different local versions" (Bielsa \& Bassnett 2009, 72), while others depend strongly on their originals (Valdeón 2005, 215), producing almost identical target language versions. While considerable amount of research is available on identifying and describing stereotypical translation strategies that accompany news translation, the actual reasons motivating these (such as certain generic norms, text building strategies) have received scant attention. Empirical research on translation has shown that translated texts "differ" from native texts, and this difference (or strangeness) may be captured primarily in textual phenomena (Károly 2007; Klaudy 1987; 2006; Toury 1986). The aim of this paper is to explore this phenomenon within the domain of news translation, by focusing on one aspect of textuality, namely cohesion.

In translation studies the primary aim of cohesion analysis has been to identify so called "shifts in cohesion" (Blum-Kulka 1986, 21) in the case of various language pairs and translation directions. The term "shift" is used to refer to cases when a cohesive device appearing in the source text is omitted or replaced by one from a different category. There is a difference between obligatory shifts (Toury 1980) dictated by the linguistic systems of the source and target language and optional shifts attributable to stylistic, ideological or cultural preferences (Bakker et al. 1998, 228). Shlesinger $(1995,196)$ classifies textual shifts by their causes, which may be (1) language-specific preferences, (2) norms related to particular text types and/or (3) the tendency for a translated text to be more explicit than its source (the explicitation hypothesis) ${ }^{1}$ which is assumed to be a universal of translation.

The translators' intention to create a target text with a higher level of explicitness raises further questions related to referential ${ }^{2}$ and lexical cohesion, as this strategy might clash with another universal of translation, related to the manner of repetition. According to the so-called "repetition avoidance hypothesis", target texts generally contain fewer instances of verbatim repetitions than texts originally produced in the given language (Baker 1993). Pronominal substitution and the use of synonyms play a significant role in avoiding repetition. This is important in translation as

${ }^{1}$ Explicitation is a (conscious or instinctive) translation strategy, whereby information that appears implicitly in the source text becomes explicit in the target text (Vinay \& Darbelnet 1995).

${ }^{2}$ Due to its anaphoric and cataphoric nature, reference is a type of repetition. 
the translator has to decide - depending on the systemic characteristics of the given languages and the norms that regulate their use - whether to use verbatim repetition of the word or to resort to other means of repetition, such as for example a reference item (e.g., a personal pronoun).

The following corpus-based investigation explores the different types of cohesion and the quality of cohesive ties connecting sentences in texts, based on a parallel corpus of Hungarian-English news texts. The study merges both quantitative and qualitative methods of data analysis. Based on the results, claims will be formulated regarding the nature and frequency of shifts of cohesion accompanying translation and the extent to which shifts are motivated by the systemic differences between the two languages, the stereotypical norms characterizing the given form of translation (news translation) and/or the genre investigated (the news story). The investigation ${ }^{3}$ is guided by the following research questions:

1. Do shifts of cohesion characterize the translation of news texts from Hungarian to English?

2. How do the systemic features of the languages in question, the form of translation and the characteristics of the genre influence the quality and frequency of shifts?

\section{Shifts in cohesion in news translation}

\subsection{Research on cohesion}

The most comprehensive description of the cohesive features of the English language is offered by Halliday and Hasan (e.g., Halliday \& Hasan 1976; Halliday 1985; Hasan 1984; Halliday \& Matthiessen 2004). The current analysis is based on their work so that comparison between results provided by this paper and previous research is possible. According to Halliday and Hasan's theory, textuality is the result of cohesive links created between various elements of the text, referred to as "ties". Based on the study of cohesive ties, among other things, the differences between written and spoken discourse, the stereotypical characteristics of certain genres as well as individual and cultural features of text production may be described.

\footnotetext{
${ }^{3}$ The corpus was built with the support of the Hungarian Scientific Research Fund (OTKA, project number: K83243) and the research was sponsored by the Bolyai Research Grant.
} 
Five types of cohesion exist in English: reference, substitution, ellipsis, conjunction and lexical cohesion. ${ }^{4}$

In Halliday and Hasan's (1976) view, reference comprises grammatical elements that are only meaningful insofar as they refer to another element in the text. There are three types of reference in English: (1) personal reference: including not only reference to persons, but reference to objects, as well as to other parts of the text (using personal pronouns, possessive pronouns, e.g., he, mine, her); (2) demonstrative reference: demonstrative particles and the definite article (e.g., this, that, these, those, here, there, then; the); (3) comparative reference: adjectives and adverbs expressing identity, similarity, difference, qualitative or quantitative comparison (e.g., the same, similar, different).

Halliday-Hasan (1976) treat reference as a type of semantic relation which creates connections between meanings in the text, while substitution is defined as a lexico-grammatical (actually grammatical) relation. It is important to emphasize that in the case of substitution, in the English language, the substituting element has the same structural function as the element it substitutes. The case is not always the same with reference. Halliday and Hasan treat ellipsis as grammatical relation as well, because in their view, substitution and ellipsis realize very similar processes: in the case of substitution, one element of text is substituted by another element, while in the case of ellipsis, the element of text is omitted (= zero substitution). According to Halliday and Matthiessen (2004, 535), ellipsis "makes it possible to leave out parts of a structure when they can be presumed from what has gone before". In the English language, the element of substitution may take a nominal, verbal or clausal function, therefore the corresponding types of substitution are: nominal (one, ones, the same), verbal $\left(\right.$ do, be, have) and clausal $(s o, n o t) .^{5}$

${ }^{4}$ Work by Halliday and Hasan offer a detailed description of cohesive devices and the specific realisations of their sub-types (e.g., the definite article functioning as referential cohesion), therefore only a summary of their main features is provided here, accompanied by a few examples for illustration. It needs to be noted though that Halliday and Hasan's work is not the only theory of cohesion. A more recent account of their theory is published in Halliday \& Matthiessen (2004) and a different approach (in view of the role cohesion plays in coherence as well as the categories that constitute cohesion) is available in e.g., de Beaugrande \& Dressler (1981); Enkvist (1990); Grabe \& Kaplan (1996); Hardy \& Leuchtmann (1996); Hoey (1991); Sanders et al. (1992).

${ }^{5}$ For example: My axe is too blunt. I must get a sharper one (=nominal); You think Joan already knows? - I think everybody does (= verbal); Is there going to be an earthquake? - It says so (= clausal substitution). 
In the case of ellipsis, a part of the text is omitted, but this does not mean the reader is unaware of the omitted part; to the contrary: when an ellipsis occurs, something evident is omitted from the text. According to Halliday and Hasan, there is a structural condition to ellipsis: it may only occur in a sentence with a structure that connects to the preceding sentence's structure in such a way that the information is inferable. Naturally, ellipsis may occur within a sentence, too, but in Halliday \& Hasan's (1976, 146) theory, ellipsis as a grammatical cohesive device functions only between sentences. There are three types of ellipsis: nominal, verbal and clausal. ${ }^{6}$

The fourth type of cohesive device is conjunction. Connectives that belong to the category of conjunction are not cohesive in their own right: their cohesive force comes from their special meaning, rather than their anaphoric nature. They form a semantic connection that enables inference of the relation between preceding and following parts of the text. Conjunctions establish connections between parts of the text that follow one another but are not structurally connected. Halliday \& Hasan (1976) distinguish between four types of conjunctions depending on the nature of the relation they mark in the text and emphasize that these include not only grammatical (e.g., so, but), but lexical elements as well (e.g., in conclusion, as a result): (1) additive (e.g., in addition, besides, in other words), (2) adversative (e.g., however, but, instead), (3) causal (e.g., so, hence, because), (4) temporal (e.g., then, finally, meanwhile).

As opposed to cohesion created by grammatical elements, lexical cohesion is created by relations between various lexical units of the text. The taxonomy created by Halliday and Hasan (1976) has been revised by Hasan (1984) to correct some theoretical and methodological deficiencies of the original theory. Hasan identifies two major categories of lexical cohesion (table 1): (1) "general lexical relations", which comprise general lexical-semantic relations (repetition, synonymy, antonymy, hyponymy, meronymy) and (2) text-dependent relations, in which case instead of two lexical units connected by a general semantic relation, the connection is established through context. Hasan defines the latter types of lexical cohesion as "instantial relations". This taxonomy offers a more accurate definition of the categories and thus facilitates more reliable analysis. Therefore, the lexical analysis reported on in this paper relies on Hasan's work. ${ }^{6}$ For example: Which last longer, the curved rods or the straight rods? The straight
are less likely to break (= nominal); Have you been swimming? Yes, I have
(= verbal); What was the Duke going to do? Plant a row of poplars in the park
(= clausal ellipsis).
Acta Linguistica Hungarica 60, 2013 
Table 1: Categories of lexical cohesion (based on Hasan 1984)

\begin{tabular}{|c|c|}
\hline \multicolumn{2}{|r|}{ General semantic relations } \\
\hline 1. repetition: & leave, leaving, left \\
\hline 2. synonymy: & leave, depart \\
\hline 3. antonymy: & leave, arrive \\
\hline 4. hyponymy: & travel, leave (including co-hyponymy, e.g., desk, table) \\
\hline 5. meronymy: & hand, finger (including co-meronymy, e.g., finger, thumb) \\
\hline \multicolumn{2}{|r|}{ Instantial (textual) relations } \\
\hline 1. equivalence: & the sailor was their daddy; you be the patient, I'll be the doctor \\
\hline 2. naming: & the $\boldsymbol{d o g}$ was called Toto; they named the $\boldsymbol{d o g}$ Fluffy \\
\hline 3. semblance: & the deck was like a pool; all my pleasures are like yesterdays \\
\hline
\end{tabular}

\subsection{Research on cohesion in translation}

\subsubsection{Overview of research related to the universals of translation}

The target language (re)creation of cohesion has been shown to be related to certain tendencies claimed to figure as universal features of translation. In what follows, the results of relevant research focusing on various language pairs and translation directions will be reviewed. The translation universals in question involve the explicitation hypothesis and repetition avoidance hypothesis.

Baker (1992) compares English with several other languages (Hebrew, Brazilian Portuguese, Japanese, Chinese, Arabic, German and Spanish). According to her observations, the use of cohesive devices depends not only on the language, but also on genre and style. In the case of connectives, for instance, she found that when translating English texts into German, the number of connectives increases. The use of the connective and for instance poses a problem, because in English it is used in a broader variety of cases, whereas in German, more explicit connectives are preferred. As to devices of lexical cohesion, Baker investigated the use of repetitions and found that in Arabic, Hebrew and Greek, repetitions are more widely used (and tolerated) than in English or Spanish. When translating English to Japanese or Chinese, pronoun references shift in her corpus: instead of pronoun references, translators seem to prefer lexical repetitions.

Shlesinger (1995) examines shifts in cohesion related to a specific type of translation, namely simultaneous interpreting, in the case of the 
English-Hebrew language pair. She identifies a decrease in the number of referential ties in Hebrew target language discourse, which seems to contradict the explicitation hypothesis. On the other hand, both from English to Hebrew and Hebrew to English, interpreters tend to use devices of lexical cohesion instead of substitution and ellipsis, which verifies the hypothesis. Regarding conjunctions, Shlesinger found that interpreters keep most of the additive and causal conjunctions, while often omit informative conjunctions. Within the category of lexical cohesion, she examined repetition: although there appear considerable shifts related to repetition, ties omitted are inserted in later parts of the text, therefore the quantity of shifts overall is not significant. As regards collocations, the number of shifts is notable: interpreters often omit or alter collocations. Shlesinger explains this phenomenon by lack of background knowledge and the problem of linguistic inference, which causes interpreters to fail in finding functionally equivalent target language variants.

Polo (1992) explores the English-Spanish language pair and popular scientific texts. He concludes that the Spanish translations use significantly fewer lexical repetitions than the English source text; instead of repetition, the translator typically uses pronouns, synonyms and hyponyms. Polo explains this phenomenon by the fact that in Spanish, lexical repetition is seen as a sign of poor style and is therefore avoided.

Englund Dimitrova (2005) takes a look at conjunction in RussianSwedish translation. She observes that implicit logical relations in Russian are generally made explicit by translators, adhering possibly to target language norms. As to lexical repetition, she found that Swedish translations are characterized by the avoidance of repetition, similarly to what Polo (1995) saw in the case of Spanish translations.

Vehmas-Lehto (1989) examines the translation of conjunctions in Russian and Finnish news texts. Her corpus-based study concludes that there is a significant shift in the use of connectives in translation, similarly to the Russian-Swedish language pair mentioned above.

Svindland (1992) analyzes a corpus of English and Norwegian literary texts and their translations, focusing on the distribution of the connectives and and or and their Norwegian counterparts og and eller. While the Norwegian $o g$ is frequently translated as or instead of and into English, there seems to be no corresponding case in the other language direction. Svindland argues that English or has a wider distribution than eller.

Rogers (1997) observes the relations between synonymy and equivalence in English-German special-language texts. Her study reveals the importance of the translator's decision in using an equivalent target lan- 
guage version of a source language expression, or applying synonyms/hyponyms instead in a given context. Choosing an adequate target language expression in the given context depends on the compounds and collocations the given expression typically appears in, as well as on its ability to change word class. Rogers claims that the possible set of synonyms is context-dependent in both the source and target language.

Becher (2011a) explores shifts producing explicitation and implicitation in business texts, with regard to the English-German language pair. He challenges the status of explicitation as a universal of translation, i.e., that it would be inherent in the translation process. He claims that shifts are caused by lexico-grammatical and pragmatic differences instead, and argues for Klaudy's asymmetry hypothesis as a valid basis for researching explicitation/implicitation rather than the explicitation hypothesis. According to Becher, the translators' explicitation behaviour depends on the communication norms of the given culture, resulting from translation norms, the stylistic preferences of the target language audience, or registerdependent conventions, etc.

In sum it may be concluded that while considerable research has been conducted on the explicitation and the repetition avoidance hypotheses, as well as on examining genre-specific tendencies, their respective focus has been rather diverse (typically restricted to one particular cohesive device analyzed in isolation) and their findings hard to compare (because of the diversity of language pairs and text types/genres investigated). The analysis reported on in this paper therefore sets out to offer a systematic investigation of all (non-structural) cohesive devices and to reveal the relations between cohesive phenomena and elements of the discourse structure (event structure) of the genre in question (news text), in HungarianEnglish translation. To our knowledge, with regard to this genre and language pair, no empirical data is available so far that would encompass the (re)creation of all of the cohesive devices in translation. ${ }^{7}$ Owing to the special characteristics of the genre (comprising written, formal texts, close in style to scientific discourse), the results may be compared with the findings of previous research focusing on similar text types (e.g., media text, popular scientific text, scientific text) and novel insights may be obtained regarding translation universals.

${ }^{7}$ A comprehensive analysis of cohesive devices was carried out by Károly et al. (2000) and Makkos (2010) regarding the Hungarian and English language pair. However, these studies analysed translations produced for language testing purposes, which is governed by different norms than "professional" translation, and therefore, their results are not or only partially comparable with analyses carried out on professional translation. 


\subsubsection{Results of research related to the Hungarian language}

Heltai and Juhász (2002) carried out an analysis focusing on third person pronouns (he, she, it, they, as well as ö 's/he', az 'it', ök 'they', azok 'them') and demonstrative pronouns (this these, that, as well as $e z$ 'this', ezek 'these', az 'that', azok 'those') in literary and academic texts in both English-Hungarian and Hungarian-English translation. Their research was based on the relevant theories of Szikszainé Nagy (1999); Tolcsvai Nagy (2001); É. Kiss et al. (1998); Pléh (1998) and Kocsány (1995). Their analysis shows that English personal pronouns are typically realised by zero in Hungarian translation, by a noun phrase, or by a conjugated verb. The inflectional morphological element on the Hungarian conjugated verb has some functions similar to the English personal pronoun. The personal pronoun it does not have a Hungarian equivalent, however, translators often use a demonstrative pronoun (chiefly $e z$ 'this') instead. Consequently, Heltai and Juhász attribute greater functional loading to demonstrative pronouns in Hungarian (op.cit., 52). Their analysis also shows that Hungarian operates with few personal pronouns, which are often automatically inserted when translating from Hungarian to English. Although in the case of demonstratives the English and the Hungarian system is very similar, the discourse functions of the various pronouns differ in the two languages (e.g., the cataphoric use of the English pronoun this is less frequent in Hungarian, and the pronoun ezek 'these', used to refer to people, may carry a pejorative meaning). At the end of their study, the authors conclude that the English-Hungarian translation direction is characterized by obligatory implicitation (generalization), that is, English pronouns are typically not translated into Hungarian, and they are rarely substituted by a noun phrase; on the other hand, when translating from Hungarian to English, there is typically an automatic explicitation.

Jenei (2006) has described the translational behaviour of references. Her work is based on the hypothesis that reference has an effect on the quality of texts, and therefore in translation the target language realisation of references influences the quality of the translated text. Applying Halliday \& Hasan's (1976) and Hasan's (1984) taxonomy, she compared the realisation of reference (personal reference, demonstrative pronouns and comparatives) in a Hungarian and a Spanish translation of an English literary text, and used her results to describe the typical strategies translators resort to to overcome systemic differences between languages. Her corpus demonstrated significant differences in the use of personal pronouns. Merely $16 \%$ of the personal pronouns are translated as personal pronouns in Hungarian, and only when the pronoun is stressed in the 
source language sentence. In every other case the translator uses verbal inflections (55\%) or a possessive nominal suffix (17\%). As for demonstratives, $80 \%$ of English definite articles are realised in translation into Hungarian. Other strategies include the use of a demonstrative + definite article, possessive nominal suffix or other categories. $32 \%$ of other demonstratives have no Hungarian equivalents (e.g., that/there $\rightarrow e z / e z a / i t t)$, therefore these cases constitute shifts. As for comparatives, there is a considerable similarity between the Hungarian and English texts, as $86 \%$ or them are realised by words belonging to similar categories in the target language.

Klaudy and Károly (2000) investigated the discourse function of lexical cohesion in texts translated from English into Hungarian. They based their analysis on the assumption that the translators' main aim is to communicate the global meaning of the text (Neubert \& Shreve 1992, 139); therefore, in the case of a good translation, "the global meaning of translation, recontextualized as an L2 text" is matched to "the original global meaning of the source text" (idem.). They applied an analytical model developed by Károly (2002), which is a revised version of Hoey's (1991) lexical repetition model. Hoey's model treats sentences as "interrelated packages of information" (1991, 43) and - based on a systematic analysis of repetitions - can identify the so called central sentences of the text (i.e., the ones that make multiple connections with other sentences and thus are claimed to be "germane to the development of the theme(s) of a text"; 1991, 43). Klaudy and Károly (2000) analysed three kinds of text: an English news article and a total of 20 translated Hungarian versions (10 by professional translators and 10 by novice translators). Their statistical and qualitative analyses show significant differences in the nature and the combination of lexical repetitions in the two groups. On the one hand, professional translators use a higher number of simple lexical repetitions than beginners; a phenomenon the authors attribute to the fact that professional translators have greater awareness of the characteristics of the text type (here the text type is highly informative and factual, which gives little room for the translator's creativity). On the other hand, statistical analyses show that professional translators also create significantly more repetition links, that is, they "mark" the central sentences (communicating the main theme(s)) of the text by repetitions.

In another study, Károly (2010) explored the types of lexical repetition and the combinations of repetition links connecting sentences in a text. Using Hoey's (1991) lexical repetition model, she analysed a corpus of 20 original Hungarian news articles and their English translations, aiming to identify possible shifts in repetition, with special regard to relevant 
translation universals (namely, the explicitation hypothesis and the repetition avoidance hypothesis). She concludes her quantitative and qualitative analyses by showing that although shifts may be identified in the target language texts both in the quality and the quantity of lexical repetitions used, the differences between sources and translations are not significant statistically. Thus the corpus does not provide evidence for the validity of the repetition avoidance hypothesis. At the same time, there are differences in the patterns of repetition in the two sub-corpora, resulting in shifts in central sentences in 18 texts (of the 20). In most of the cases, the repetition matrices created based on the repetition links show a greater density of repetitions in the English texts, that is, more information seems to be "marked" by repetitions in these texts, therefore making it easier for the reader to process the information content. Although these results harmonize with the explicitation hypothesis, the corpus offers examples for the opposite too; therefore, the author expresses the need for further research.

Károly et al. (2000) analysed English-Hungarian translations carried out for the purposes of language testing (intermediate level examination), aiming to distinguish between high- and low-rated translations on the basis of the patterns of cohesion used by the translator. Their study was based on Halliday \& Hasan's (1976) and Hasan's (1984) work and involved a comparison of all cohesive devices in high- and low-rated translations, in the source text and the "key" version provided by a professional translator. As for referential cohesion, the two groups' translations did not show notable differences; compared to the key, differences only occurred in the use of pronouns. The authors explain this tendency by the professional translator's aim to decrease the level of redundancy by reducing the frequency of references (e.g., omitting either the personal pronoun or the pronominal suffix in Hungarian). As for the similarity between high- and low-rated translations, the authors argue that language learners at this level are already familiar with the relevant grammatical structures and thus rarely make mistakes of this type. In the case of substitution and ellipsis, the high-rated translations provided a more accurate target language version than the low-rated ones. As for connectives, the authors identified three major differences between the language learners' versions and the key translation. On the one hand, language learners used conjunctions belonging to a lower/simpler stylistic register (e.g., ezért lit. 'so' instead of igy hát 'and thus'), possibly due to insufficient language knowledge/skills to identify shades of meaning at this level. On the other hand, language learners used explicit ties where the key translation omitted them or inserted another grammatical element 
instead. The third difference was the frequent misinterpretation of logical relations by language learners (e.g., translating and as és 'and' in instances where but would have been correct). An interesting difference between the two groups was that high-rated translations often expressed logical relations implicitly, while low-rated translations marked them explicitly, a phenomenon also possibly related to limitations of language use. As for lexical cohesion, they found considerable difference between the two groups: high-rated translations operated with a higher number of repetitions and antonyms, and used repetitions with derivational and inflection changes more frequently than the source text. Therefore the text became more readable and easier to follow, thus possibly producing higher rater appeal. Despite the differences, Károly et al. conclude that their corpus overall does not verify the hypothesized causal connection between the use of cohesive devices and the quality of translations (only three types of ties showed considerable differences between high- and low-rated translations: lexical cohesion, substitution and ellipsis).

\subsection{News translation: the stereotypical nature of translating news texts}

The news story, as a genre, is characterized by several stereotypical features, and news translation, as a special form of translation, also affects considerably the target language realisation of text level variables (Gottlieb 2010). These, together with the translator's decisions (to stay loyal to the source text or to make changes), are in close relationship with the use of cohesive devices. Therefore, in what follows, the generic characteristics of the news story will be described and research on news translation as a special form of translation will be reviewed.

\subsubsection{The generic characteristics of the news story}

Bell's $(1991 ; 1998)$ work on the discourse structure of the news story, heavily influenced by van Dijk's (1988) theory, has been influential in the identification of the generic characteristics of the genre. News stories consist of three key components: (1) attribution (news agency, journalist's byline), (2) abstract (headline and lead), and (3) story (episodes and events). Within the story, events contain several moves: attribution, actors, action, setting, follow-up (action after main event), commentary (the journalist's or news actor's observations and evaluative comments on, or expectations of the events, which may provide context to help readers understand the news story), and background (consisting of verbal reaction by other parties, 
or non-verbal consequences; covers any action after the main action of the event). This paper explores whether optional shifts of cohesion occur at any point of the event structure and whether these shifts are in any way related to news content (i.e., are conducive to shifts of content). This investigation is necessitated by the very nature of the corpus: the analytical news article. According to Reiss's (2000) typology, this genre falls into the category of content-focused texts, where the descriptive function is dominant. Such texts require "invariance in transfer of their content" (op.cit., 30) and the translation method is selected accordingly. She claims that in selecting the translation method "[t]he target language must dominate, because in this type of text the informational content is most important, and the reader of the translation needs to have it preserved in a familiar [...] linguistic form" (ibid., 31).

\subsubsection{Research on news translation as a special form of translation}

The majority of research on news translation has focused on exploring the special role(s) of the translator and the ensuing translation strategies. According to the findings of research, the translator of the news text has a complex role. Vidal $(2005,386$; cited by Bielsa 2007, 137) states that " $[\mathrm{t}]$ he news translator is, maybe because of the nature of the medium in which she writes, a re-creator, a writer, limited by the idea she has to recreate and by the journalistic genre in which her translation has to be done". The nature of the news translation requires specific skills and abilities that change the status of both the agent and the process: the translator becomes an author in the target language, and from simple text reproduction, news translation becomes a form of creative production. The form and content of the source text is often modified in order to make the translation a relevant piece of writing that corresponds to the background knowledge of the target text reader. Translators most often change the title or the subheading, but they also tend to omit unnecessary information, insert pieces of background information, change the order of the paragraphs, and/or summarize information (Bielsa 2007, 142-143).

\section{Method}

\subsection{The corpus}

The corpus is composed of the summary sections of translated English analytical news articles and their corresponding Hungarian originals retrieved 
from the website of Budapest Analyses, one of Hungary's internet based news magazines visited mainly by foreigners within and beyond the country's borders. Budapest Analyses, as its name also suggests, publishes analytical articles on political, economic, financial, social and cultural issues and events taking place in or related to Hungary. The corpus contains 20 Hungarian summaries and their English translations, altogether 40 texts (6,658 words). The identity of the translator(s) of the articles is not revealed. The summaries have been randomly selected from the period between 2006-2009. The summary fulfils an important discourse function: it indicates the main message of the article and mentions the most important topics and supporting arguments to be discussed and elaborated on in detail. Its contents and rhetorical development is characterized by an analytical, critical, argumentative approach, therefore it belongs to the category of "argumentative news genres" (Gottlieb 2010, 199). When translating such texts, translators typically stay loyal to the content and form of the original.

\subsection{Analytical decisions}

As a result of the systemic differences between the two languages, cohesion in English is not fully identical with that in Hungarian (for a description of cohesion in Hungarian see Szikszainé Nagy 1999 and Tolcsvai Nagy 2001; for a translation-oriented comparison of some of the distinctive features of English and Hungarian see Klaudy 2003). These differences have significant consequences for translation both in terms of the quantity and the quality of cohesive devices applied. To obtain a comprehensive picture of how cohesion unfolds in the Hungarian and in the English corpus, all cohesive ties appearing in source texts and translations formed part of the investigation (not only the translations of cohesive ties in the source texts). The study focuses on cohesive ties that establish relations between sentences (or larger parts of text) (Halliday \& Hasan 1976, 9). The bilingual analysis $^{8}$ called for certain methodological decisions to ensure consistency and reliability.

The analysis of reference, due to the systemic differences between Hungarian and English, raised certain issues that had to be taken care of:

(a) In English, the use of personal pronouns is obligatory because of the special characteristics of conjugation. In Hungarian, on the other hand,

8 The analytical decisions relating to the differences between the two languages were based on Tolcsvai Nagy (2001) and Szikszainé Nagy (1999). 
the inflectional morphological element on the verb has the function to give personal reference (and also other information on temporality and definiteness), therefore the Hungarian verbal (personal) suffix is identified as personal reference (e.g., foglaljuk - We; see (1)):

(1) Personal reference in Hungarian and in English

\begin{tabular}{|c|c|}
\hline $\begin{array}{l}\text { Hungarian source text } \\
\text { (text } 05 \mathrm{H} \text {, sentence } 5) \text { : }\end{array}$ & $\begin{array}{l}\text { English target text } \\
\text { (text } 05 \mathrm{E} \text {, sentence } 5) \text { : }\end{array}$ \\
\hline $\begin{array}{l}\text { Ezúttal a 2004. évi XXII. törvény } \\
\text { néven kihirdetett „Lex Szász” } \\
\text { vonatkozásában felmerült újabb alkot- } \\
\text { mányossági kifogásokat foglaljuk össze. }\end{array}$ & $\begin{array}{l}\text { We now assess newly emerged con- } \\
\text { stitutional worries with regard to the } \\
\text { legislation "Lex Szász", endorsed as } \\
\text { Act XXII of } 2004 \text {. }\end{array}$ \\
\hline
\end{tabular}

(b) The possessive construction also differs in English and Hungarian. In Hungarian, one way of expressing it is that the possessor noun or pronoun (that precedes the possessed noun) is inflected for the dative case, and the possessed noun receives a possessive/person suffix (e.g., Peter's/His book $=$ Péternek $a / A z$ 路 könyve; where both the dative suffix on the possessor noun and the following definite article, or the article and the pronoun may be omitted; for more details see Törkenczy 1997, 71). In the current corpus, in cases where the English language uses a possessive pronoun, Hungarian uses a corresponding possessive suffix on the possessed noun (e.g., felvetéseit-his; see (2)). These cases have also been identified as manifestations of reference.

(2) Possessive pronoun vs. possessive suffix

$\begin{array}{ll}\begin{array}{l}\text { Hungarian source text } \\ \text { (text 03H, sentence 4): }\end{array} & \begin{array}{l}\text { English target text } \\ \text { (text 03E, sentence 4): }\end{array} \\ \text { A miniszterelnök szándéka nemcsak } & \text { The efforts of the prime minister } \\ \text { visszatetszést szült a Szentszéknél, } & \text { evoked not only displeasure at the } \\ \text { hanem vendéglátói rendre vissza is } & \text { Holy See, but his hosts repeatedly } \\ \text { utasították felvetéseit és határozott } & \begin{array}{l}\text { rejected his suggestions as well as } \\ \text { expressed resolute messages for the }\end{array} \\ \text { üzeneteket fogalmaztak meg a magyar } & \text { Hungarian government. } \\ \text { kormány számára. } & \end{array}$

It is a special trait of lexical cohesive relations that particular lexical units may form not only one tie in the text, but they can form relations of varying types with a number of lexical units. In such cases, each tie was taken into account separately in the total number of ties. For example, the word romániai (lit.: 'Romanian') in sentence 1 of text $01 \mathrm{H}$ (Hungarian text) is a simple repetition of the same word in the title (sentence 0), however, the word romániai also forms a meronymic relation with the word erdélyi (lit.: 'Transylvanian') in sentence 2. 
There are inconsistencies in the literature regarding the treatment of lexical repetitions realised by verbal derivations or inflections (e.g., Hasan's (1984) taxonomy includes only inflectional variants, while Hoey's (1991) repetition model also takes derivational variants into account). As this analysis follows Hasan's (1984) theory, besides the verbatim repetitions of lexical units only repetitions with inflectional change are taken into account (therefore e.g., the word romániai (lit.: 'Romanian') in sentence 2 of Hungarian text $14 \mathrm{H}$ and the word Romániában (lit.: 'in Romania') in sentence 2 are not treated as a cohesive tie in this paper). Making such a restriction though, purely on a formal basis, is not without problems as, semantically, the two expressions romániai (lit.: 'Romanian') and Romániában (lit.: 'in Romania')) have a lot in common, they overlap each other. Furthermore, retaining the distinction between inflectional and derivational change runs counter to current morphological theory too that shows an increasing tendency towards combining rather than separating them (e.g., Anderson 1992; Di Sciullo \& Williams 1987; Halle 1973). There have been attempts in the field of discourse analysis to modify earlier taxonomies of lexical cohesion on linguistic typological and language specific grounds on a semantic basis (e.g., Gutwinski 1976; Károly 2002), but none of these address the problem from a translation-oriented perspective. Therefore a significant step of future research could be a translation-based (i.e., translational data based) and translation-oriented (i.e., addressing the differences between languages that surface as problems in translation) modification of earlier theories, involving further text types and genres. ${ }^{9}$

The corpus includes lexical units comprising one or more words (simple and compound words). Using Károly's (2002, 97) definition of the "lexical unit" (i.e., "a unit whose meaning cannot be compositionally derived from the meaning of its constituent elements"), such units are analyzed as one lexical unit here. Therefore, expressions such as a köztársasági elnök (02H-2) - the President of the Republic (02E-2), a katolikus egyház (03H-1) - the Catholic Church (03E-1), a határon túli magyarok $(04 \mathrm{H}-0)$ - the Hungarians beyond the borders $(04 \mathrm{E}-0)$ or a narancsos forradalom (06H-4) - the orange revolution (06E-4) are identified as one unit (that can form ties with other lexical units). Similarly, compound proper names also classify as one unit, such as a Romániai Magyar Demokrata Szövetségböl (01H-1) - of the Democratic Alliance of Hungarians in Romania (01E-1), az Erdélyi Magyar Nemzeti Tanács (01H-5) - the Transyl-

${ }^{9}$ The latter is important as research (e.g., Baker 1992) has shown that cohesion varies not only according to language, but also according to text type. 
vanian Hungarian National Council (01E-5), a Lex Szász (02H-0) - Lex Szász (02E-0). Hyphenated words that have closer connections in the text (e.g., a magyar-szentszélisi kapcsolatok $(07 \mathrm{H}-0)$ - Hungarian-Vatican relations (07E-0), or a magyar-dél-afrikai kapcsolatok (09H-0) - Hungarian-South-African relations (09E-0)) are regarded as one unit when repeated later in the text.

To ensure the reliability of the analysis, double coding was conducted: each text was coded by two trained analysts independently. The results of the two codings were compared and controversial cases were discussed. Final decisions were made in compliance with the relevant literature on theory and/or research methodology.

In order to test the significance of the difference between source texts and translations, paired-sample $t$-tests were conducted on all variables using SPSS 11. The statistical analysis was complemented by an in-depth qualitative analysis of the data in order to reveal possible links between cohesive patterns and the event structure of the news stories which, ultimately, might lead to changes in news content.

\subsection{Sample analysis}

This section demonstrated the methodology of analysis using an excerpt from one of the Hungarian source texts and its translation, see (3):

(3) Sample analysis of lexical cohesive devices in text 16

Hungarian source text 16:

0 . $[$ Amerikai $][$ rakétavédelmi rendszer] [telepítése]

1. Azon REP [amerikai] tervek híre, hogy az USA egy MER [radarállomás] REP [telepítéséről] tárgyalna [Csehországgal $]$, és MER $[10$ ún. védelmi elfogóeszköz] REP [telepítésének] engedélyét kéri [Lengyelországtól], felzaklatta a kedélyeket [Oroszországban] és [Európában] is.

2. MER [Moszkvából $]$ azonnali és igen éles válaszok érkeztek, REP [MER [Európában]] pedig azon politikusoknak hallatszik erősebben a hangja, akik inkább hajlanak az HIPO [orosz], mint az REP [amerikai] érvek felé.
English target text 16:

0 . The $[$ deployment $]$ of the $[$ American] [missile defence system]

1. The news that the USA would like to negotiate with the $[$ Czech Republic] concerning the REP [deployment] of a MER [radar station] and a request to Poland about the REP [deployment] of $M E R[10$ so-called long-range groundbased missile defence interceptors] in $[$ Poland $]$, rattled nerves in $[$ Russia $]$ and $[$ Europe $]$ alike.

2. MER $[$ Moscow $]$ reacted promptly and sharply, while in REP[MER[Europe]], politicians that are inclined more towards the HIPO [Russian] stance than to the REP [American] one - are more vocal. 
The analysis was carried out manually. First, the texts were divided into sentences, and for ease of reference, they were numbered (titles were indicated by 0 ). The cohesive units are indicated by square brackets, their type is shown in subscript. The antecedent units appear in italics in square brackets. Related units are listed in Appendix 1.

\section{Results and discussion}

\subsection{Results of the quantitative analysis of cohesive variables}

The results of the quantitative analysis are summarized in table 2 .

Table 2: Frequency of cohesive devices in the Hungarian-English corpus

\begin{tabular}{llllll}
\hline & \multicolumn{3}{c}{ Hungarian } & & \multicolumn{2}{c}{ English } \\
\cline { 2 - 3 } \cline { 5 - 6 } \cline { 5 - 6 } & Total & Mean/text & & Total & Mean/text \\
\hline Personal reference & 23 & 1.15 & 19 & 0.95 \\
Demonstrative reference & 134 & 6.65 & & 133 & 6.65 \\
Comparative reference & 13 & 0.65 & & 11 & 0.55 \\
Reference Total & 170 & 8.50 & & 163 & 8.10 \\
\hline Conjunction & 20 & 1.00 & 20 & 1.00 \\
\hline Substitution & 0 & 0.00 & 1 & 0.05 \\
\hline Ellipsis & 3 & 0.15 & 6 & 0.30 \\
\hline Repetition & 203 & 10.15 & 210 & 10.50 \\
Synonymy & 67 & 3.35 & 59 & 2.95 \\
Antonymy & 8 & 0.40 & 8 & 0.40 \\
Meronymy & 47 & 2.35 & 45 & 2.25 \\
Hyponymy & 132 & 6.60 & 138 & 6.90 \\
Instantial relations & 41 & 2.05 & 42 & 2.10 \\
Lexical cohesion Total & 498 & 24.90 & 502 & 25.10 \\
\hline
\end{tabular}

In contrast with previous research, the statistical analysis of the corpus ( $t$-tests on all cohesive variables) fails to show a significant difference between the two sub-corpora in terms of any of the variables (the significance value does not go below the .05 level; table 3 ). As quantitatively there are no significant shifts between source texts and their translations, the data 
does not provide evidence for the explicitation hypothesis. However, a more detailed analysis of the target language realisations of cohesive ties shows considerable shifts in terms of the quality of the cohesive pattern. These qualitative differences typically fall under two categories: differences (1) in the nature of shifts (automatic or optional) and (2) in the type of the cohesive tie established (e.g., when repetition is realised by a synonym in the translated text). The subsequent sections explore these shifts in detail, for all cohesive devices respectively.

Table 3: $t$-tests of the cohesive variables (Hungarian source text-English target text; significance value: $\left.{ }^{*} p<.05\right)$

\begin{tabular}{lclll}
\hline & $t$-value & Sig. & Mean & St. dev. \\
\hline Personal reference & .525 & .606 & .20 & 1.704 \\
Demonstrative reference & .000 & 1.000 & .00 & 2.294 \\
Comparative reference & .809 & .428 & .10 & .553 \\
Reference Total & .487 & .632 & .40 & 3.676 \\
\hline Conjunction & .000 & 1.000 & .00 & .725 \\
\hline Substitution & -1.000 & .330 & -.05 & .224 \\
\hline Ellipsis & -1.831 & .083 & -.15 & .366 \\
\hline Repetition & -.511 & .616 & -.35 & 3.066 \\
Synonymy & .940 & .359 & .40 & 1.903 \\
Antonymy & .000 & 1.000 & .00 & .459 \\
Meronymy & .623 & .541 & .10 & .7185 \\
Hyponymy & -.679 & .505 & -.30 & 1.976 \\
Instantial relations & -.224 & .825 & -.05 & .999 \\
Lexical cohesion Total & -.253 & .803 & -.20 & 3.533 \\
\hline
\end{tabular}

\subsection{Reference}

\subsubsection{Results of the qualitative analysis of referential shifts}

Qualitative analysis of the text pairs shows shifts in the nature of reference used. A large number of text pairs in the corpus (e.g., texts 02, 05, 10, 12, $14,17)$ operate with the same number of referential ties, however, their source and target language realisations differ in terms of: 
(a) the type of reference (the translator uses a different category of reference/cohesive device than the source text, see (4a)), or

(b) the position of the reference (the translator inserts a referential tie where the source text used no such cohesive device; or omits a referential tie present in the source text). This may occur automatically, owing to the systemic differences of the languages, or as a result of the translator's decision $(4 \mathrm{~b}-\mathrm{c})$.

(4) Shifts in the quality of referential ties ${ }^{10}$

a. other category:

Hungarian source text 12, sentence 8: English target text 12, sentence 8:

$\underline{A z}$ (D) érdeklődés érthető: ismert

Their (P) interest is understandable:

készletei alapján Türkmenisztán $a(\mathrm{D})$

világ 3-4. legnagyobb földgázkész-

letével rendelkező országa, amelynek

politikája nagy mértékben kihat a

in view of its known resources, Turkmenistan is the $3 \mathrm{rd}-4$ th largest in the (D) world in terms of natural gas reserves and thus its political system to környező országok, egyben $a z$ (D) a large degree affects the neighbouregész világ energiabiztonságára. ing countries, as well as the energy security of the (D) whole world.

b. insertion:

Hungarian source text 12, sentence 6 : Országát $(\mathrm{P})$ vezetve egy személyben töltötte $(\mathrm{P})$ be az államelnöki és a miniszterelnöki posztot.

c. omission:

Hungarian source text 10, sentence 8: Moldova összefüggő regionális politikát igyekszik kialakítani, amely két külpolitikai prioritását szolgálná: $a z$ (D) uniós integrációt, és a (D) szuverenitás erősítését.

English target text 12, sentence 6: As the (D) leader of his (P) country, he $\overline{(\mathrm{P})}$ simultaneously occupied the presidential and prime ministerial positions.

English target text 10, sentence 8: Moldova is attempting to formulate a comprehensive regional policy, which would serve two foreign policy objectives: $\emptyset \mathrm{EU}$ integration and the reinforcement of $\underline{\emptyset}$ sovereignty.

The in-depth, qualitative analysis also explored the validity of the repetition avoidance hypothesis. There are several examples in the corpus for the avoidance (omission) of lexical repetition, as in sentence 7 of (5), where the translator (formally) omitted the word Bizottság (lit.: 'Commission'), mentioned several times in the preceding text. It needs to be noted though that no complete omission occurs here (only from a formal perspective),

10 Abbreviations: $(\mathrm{P})=$ personal reference, $(\mathrm{D})=$ demonstrative reference, underlining $=$ shift, italics $=$ reference (or element with corresponding function e.g., verbal (personal) suffix). 
as Bizottság (lit.: 'Commission') is activated semantically for the reader in the English translation by Commissioner.

(5) Avoidance of repetition

Hungarian source text 08 :

1. Az Európai Bizottság újabb megszorító intézkedésekre szólította fel Magyarországot. [...]

3. A Pénzügyminiszteri Tanács (ECOFIN) 2005. november 8-i ülésén a Bizottság javaslatára kimondta, hogy Magyarország továbbra sem tett hatékony lépéseket az államháztartási hiány csökkentésére.

\section{A Bizottság jelentése megállapítja,} hogy Magyarország jelentősen eltér a 2005-re és 2006-ra vállalt hiánycsökkentési céloktól.

5. Emellett a jelentés kimondja, hogy a jövő évi költségvetési törvényjavaslatban tervezett hiány a GDP 5,2\%-a lesz, ám $\underline{a}$ Bizottság szerint ez sem lesz tartható ā bejelentett adócsökkentések miatt. [...]

7. Joaquín Almunia, $\underline{a}$ Bizottság pénzügyi biztosa szerint a magyar deficit egyértelmüen magasabb lesz, mint amit a magyar kormány becsült.

English target text 08:

1. The European Commission called on Hungary once again to introduce austerity measures. [...]

3. On the recommendation of the Council of Finance Ministers (ECOFIN), the Commission announced at the November 8th 2005 session that Hungary has failed yet again to implement effective measures to reduce state deficit.

4. The report of the Commission observed that Hungary has fallen well short of the deficit reduction target undertaken for 2005-2006.

5. Moreover, the report states that the fiscal deficit for next year, stipulated in the draft law, will reach $5.2 \%$ of the GDP, but in the view of the Commission even this level would not be sustainable in light of the announced tax reductions. [...]

7. The Commissioner for Finance $\underline{\emptyset}$, Joaqín Almunia opined that the Hungarian deficit will be definitely higher than that estimated by the Hungarian government.

However, taking a close look at referential ties, the corpus does not present any examples where a verbatim repetition or a synonym in the source text was realised by pronominal substitution in the target text. This is in line with Limon's (2004) results for the Slovene-English language pair: he found numerous cases where a lexical cohesive device was omitted, but not replaced by elements of grammatical cohesion. Therefore, the corpus - in terms of reference - does not verify the repetition avoidance (here: replacement by pronominal substitution) hypothesis.

As part of the qualitative analysis, we investigated whether the patterns of pronoun use in the corpora correspond to results of previous research carried out on the Hungarian and English language pair. In order to ensure comparability, the analysis was extended to include not only instances of inter-sentential pronominal reference but all other relevant 
cohesive ties in the corpus. In the English translations, only a small number of instances presented the use of personal pronouns (only 19 such cases in the entire corpus). Moreover, there was only one case where a personal pronoun was used in the Hungarian source text (although, as discussed in section 2.1, Hungarian inserts a pronominal subject in certain cases). This $5.26 \%$ ratio corresponds to Heltai and Juhász's (2002) results, who found a $4 \%$ correspondence in their corpus of literary and academic texts. On the other hand, Jenei (2006) witnessed a higher level of correspondence, namely $16 \%$, in her corpus of literary texts. The difference may be explained by genre-specific characteristics: the style and discourse structure of news articles in our analysis resembles that of academic texts, that is, texts that are primarily descriptive and argumentative, as opposed to the narrative style of literature. The tendency to reiterate characters - often by pronominal reference - over the course of the narrative is a typical feature of literary texts.

Earlier analyses of translated texts (Heltai \& Juhász 2002, Jenei 2006) show that English personal pronouns are typically realized in Hungarian as verbal inflections, $\varnothing$ or other category, possessive nominal suffix, personal pronouns and definite article. The present corpus provides evidence for three of these: verbal inflection (in $68.42 \%$ of the cases), $\varnothing(26.32 \%$ ), or personal pronouns $(5.26 \%)$. It also supports the statement that the personal pronoun it does not have a Hungarian equivalent (therefore is typically substituted by zero; Heltai \& Juhász 2002). However, this corpus does not seem to support Heltai \& Juhász's (2002) claim that Hungarian demonstrative pronouns would generally be translated as personal pronouns in English.

As for demonstrative reference, research data regarding the Hungarian-English language pair is available only for the translation of the English pronouns this and that. According to Heltai and Juhász (2002), the cataphoric use of the pronoun this is less frequent in Hungarian; it is often replaced by an adjective instead (e.g., következö 'subsequent'). The current data set also fails to provide examples for its cataphoric use: at no place in the corpus does this 'ez' occur as cataphoric reference; it always refers back to a discourse entity mentioned earlier. The anaphoric use of the pronoun that 'az' is similarly rare in Hungarian. In Heltai and Juhász's corpus it is often replaced by the pronoun $e z$ 'this'. The present corpus does not provide an example for this phenomenon.

\subsubsection{Results of the analysis of optional shifts}

The focused study of the nature and the place of optional shifts of reference is interesting as these shifts are not motivated by the differences between Acta Linguistica Hungarica 60, 2013 
the languages, but depend on the translator's decision. The corpus contains a surprisingly low number (altogether 10) of such shifts. This may most probably be put down to the previously mentioned (section 2.3.1) special characteristics of the genre (the analytical news article): being a dominantly descriptive, content-focused type of text according to Reiss's (2000) typology, translators work with methods of translation that help preserve and reproduce as faithfully as possible the source texts' contents and formal aspects in the target language.

A closer investigation of optional shifts shows that these typically

1. further specify/clarify the reference and consequently the text, thus performing explicitation (e.g., This region, Their interest, In terms of the agreement, came second);

2. occur in sentences that carry a special discourse function (i.e., in the introduction of the text - in sentences 1 or $2-$, or in its closing sentence);

3. appear in the "action" component of the event structure (in 4 cases), but also turn up in the description of the "setting" component (in 3 cases), in the formulation of the commentary (in 2 cases), and in the description of the "actors" (in 1 case). In the "attribution", "follow-up" and "background" components no optional shifts can be identified. (6) demonstrates such optional shifts.

(6) Optional shifts

Hungarian source text 01:

English target text 01:

0. A romániai magyarok autonómiája

0. Autonomy for Hungarians in Romania

1. Az 1,7 milliónyi romániai magyart képviselő politikai szervezetből, a 1. Squeezed out of the Democratic Alliance of Hungarians in Romania Romániai Magyar Demokrata Szövetségből (RMDSZ) kiszorult csoport (DAHR), which represents the 1.7 mil2003 öszén meghirdetett egy nemzeti kisebbségi autonómia-programot, mely magában foglalja a Székelyföld területi autonómiáját is. lion ethnic Hungarians in that country, a splinter group announced a programme for national minority autonomy in the autumn of 2003, which includes autonomy for the Hungarian Székely region of Transylvania.

2. Az erdélyi Székelyföldön, vagyis Hargita, Kovászna és Maros megyében él kompakt tömbben a romániai magyarságnak szinte a fele, mintegy 800.000 magyar.

2. This region, comprising Hargita (Harghita), Kovászna (Covasna) and Maros (Mure?) counties in northern Romania, has the densest population of Hungarians in the country; indeed, nearly half of the Hungarians in Romania live there, or almost 800,000 people. 
Example (6) shows shifts (in italics) that are not produced by the systemic differences between the two languages. In the event structure of the news story these two sentences describe the "actors" and the "setting" (i.e., information that are crucial from the point of view of the message and the interpretation of the text). The demonstrative that inserted in the first sentence of the translation refers back to the country name Romania. This reference does not appear in the first sentence of the source text. The references performed by the demonstratives This and there in the second sentence are also missing from the same sentence of the Hungarian text. Besides insertions, the second sentence also provides an example for paraphrase (the expression él kompakt tömbben 'lives in a compact group' becomes has the densest population) and thus a shift of reference. Here the translator expresses the idea communicated in the source text using a completely different formulation in the target language, despite the fact that the literal translation (lives in a compact group) would also have produced a well formed English sentence. Similarly differing translational solutions were identified in Jenei's $(2006,33)$ corpus of literary texts, too, in the English-Hungarian translation direction (e.g., I don't like him. vs. A szeme sem áll jól. 'His eyes don't look ok either.').

As these optional, clarifying/specifying (explicating) shifts occur in components of the event structure that contain key elements of the news story (actor(s), action, setting, commentary, i.e., elements defining who does what, where, and what the journalist thinks about it), they contribute to the faithful communication of news contents and thus to the successful processing of the text. This is an important prerequisite of successful translation in the case of content-related texts and argumentative news genres (Gottlieb 2010, 199). Therefore it may be assumed that optional shifts of reference lead to shifts of content that aid the faithful translation of news content and thus help meet reader expectations concerning the given genre. The justification of this claim, however, needs further research, involving the study of readers' perceptions of the quality/coherence of source and target texts, too.

Optional shifts primarily occur at the beginning of the texts (e.g., in text 01 mentioned above, no other optional shifts appear; only obligatory shifts of reference can be identified in the rest of the text). This harmonises with the findings of Shlesinger's $(1995,212)$ study, which argued that at the beginning of the speeches analysed significantly more shifts occur than in later sentences. Even though this is not true for all of the shifts of the present corpus, for optional shifts, some examples may be identified. 


\subsection{Substitution and ellipsis}

Substitution and ellipsis pose fewer problems in translation, since they are more grammatical in nature, and connect purely grammatical elements. The translator's choices for the possible target language versions are restricted by the grammatical systems of the two languages. The translator has to be familiar with the norms of the specific text type, and also, be aware of language-specific behaviour that governs what may or may not be omitted in a certain language (Fawcett 1997, 92).

Based on the current corpus, it may be stated that cohesive shifts regarding substitution and ellipsis classify as obligatory shifts, because they are not the results of cultural or stylistic choices, but are generated by the systemic differences between the two languages. These two grammatical cohesive devices are not typically used in the given genre, therefore, the corpus does not provide enough data to investigate the explicitation hypothesis. This section demonstrates the (primarily) qualitative analysis of these automatic shifts.

There is only one instance of substitution in the English translations, while in the Hungarian source texts there is no substitution at all. When a substitution occurs, the structural function of the substituted element is identical to that of the original element. Out of these three types of substitution (verbal, nominal and clausal), only one instance of nominal substitution can be found in the English corpus (in text 18, sentences 3 and 4: one), which does not appear in the Hungarian source text (due to grammatical reasons; see (7)).

(7) Nominal substitution inserted into the English translation

Hungarian source text 18:

3. Egyrészt meg kell szereznie a libertariánusok, az ún. értékkonzervatívok, a vallási konzervatívok, valamint a pénzügyi konzervatívok támogatását a saját pártján belül.

4. Másrészt meg kell „határoznia” magát demokrata ellenfelével szemben.
English target text 18:

3. on one hand, he should secure the support of the libertarians, the value conservatives, the religious conservatives, and the fiscal conservatives within his party;

4. on the other one, he has to define himself in opposition to his Democratic opponent.

Since ellipsis and substitution are two realisations of the same cohesive device (Halliday \& Hasan 1976), ellipsis may be seen as "zero substitution", where the substituted element is omitted. Ellipsis, therefore, occurs when an element essential to the grammatical structure is omitted, but may be inferred by context, since the ellipsis only impacted an obvious element. 
Ellipsis is an important cohesive device that helps avoid redundancy. It occurs typically within the sentence, but these instances are outside the scope of the current investigation (see section 3.2). In this paper, only those instances of ellipsis are taken into account where the omitted information may be inferred from a preceding sentence. There are 3 instances of ellipsis in the Hungarian source texts, and 6 in the English target texts. This cohesive device presents itself in both the Hungarian and English versions of text 19 (sentences 2 and 3, italicized in (8)):

(8) Ellipses

Hungarian source text 19:

2. A nagy népi kistulajdonról szóló kormányföi ötlet meghirdetésének legalább három célja van.

3. Élénkiteni a lakossági megtakarítási kedvet, friss vért ömleszteni az egyre kevesebb társaság részvényeit forgalmazó Budapesti Értéktőzsdébe és ürügyet teremteni az eddig privatizálni nem mert „szent tehenek” (Magyar Villamos Mủvek, Vízmüvek, Szerencsejáték Rt.) magánosítására.
English target text 19:

2. The announced idea of the prime minister concerning the involvement of the less affluent segments of the public in the shareholder programme had at least three objectives.

3. Namely, to encourage the public to save, infuse fresh blood into the sluggish shareholder activity at the Budapest Stock Exchange, as well as create an alibi for the privatisation of the "Holy Cow" state-owned companies (Hungarian Electricity Works, Water Works and the Lottery Rt).

It is to be noted that this is the only case where both the Hungarian and the English text operates with an ellipsis. In sum it may be claimed that these two grammatical cohesive devices occur more often in the English target texts, without a counterpart in the respective Hungarian source text.

\subsection{Conjunction}

\subsubsection{Results from the qualitative analysis of shifts of conjunction}

Based on the relevant literature, we have hypothesised that logical relations would be made more explicit in the translations, and subsequently, the target language versions would include more conjunctions than the source texts. One of the main principles of the explicitation hypothesis is that the translator increases the cohesive redundancy of the text by adding connectives (among other things) and therefore, creates a text that is easier to understand (Blum-Kulka 1986, 19). ${ }^{11}$ Since the goal of the communica-

11 According to Pym $(2005,34)$, the main motivation for explicitation is risk avoidance (e.g., because the translator would lose a customer, would not get paid, etc.). 
tion is only attained when the reader successfully understands the connections between different parts of the text, it is a priority for the translator to make cohesive relations in the given text as explicit as possible. This does not only mean that translators are more likely to add conjunctions to a text than omit them, but also that they may add conjunctions to the target language text even in cases where such a decision is seemingly not justified (Becher 2011b, 41). Although Becher (2011a) rejects the status of explicitation as a universal of translation, he still concludes that there is insertion of cohesive devices into the target text during the process of translation. He cites data from interviews by Englund Dimitrova (2005) to demonstrate the way translators justify their decisions: "I'll add a however [...] so that the contrast becomes clearer; this sentence is difficult to 'chew' [...] however it has to be [...] although it does not say so here" (Becher 2011b, 54).

Klaudy's asymmetry hypothesis also assumes the translated text to be more explicit than the original, since explicitations made in the L1-L2 language direction are often not balanced by implicitations made in the opposite, L2-L1 direction. Translators tend to carry out translation operations involving explicitation, while they often do not execute implicitations even in cases when they would be possible (Klaudy \& Károly 2005, 14). Heltai $(2003,180)$ compared an English academic text and its Hungarian translation and found that "the text in question provided numerous examples to the phenomenon that translators strive to strengthen the cohesive relations in a text by inserting connectives and making pronouns concrete".

However, as previously mentioned (in section 4.1), the corpus analysed in this paper does not show significant differences in the use of conjunctions between the Hungarian source texts and their English translations (see tables 2 and 3). There are a total of 20-20 connectives in the Hungarian and English sub-corpora, but their distribution is uneven. As many as eight out of 20 Hungarian texts do not include any conjunctions at all, there are seven texts including one conjunction, two texts with two instances, and three texts with three conjunctions. ${ }^{12}$ The low number of conjunctions in the Hungarian corpus may be explained by the fact that the Hungarian language tends to use different devices to express logical relations between

Risk means any issue that would obstruct co-operation between the communication partners.

${ }^{12}$ In this paper, conjunctions establishing a connection between sentences are regarded as cohesive (Halliday \& Hasan 1976, 232). Thus the translator's decision to divide a sentence into two or combine two sentences to form one may affect the number of conjunctions. 
sentences in a text (Szikszainé Nagy 1999, 190). The explicit realisation of logical relations depends on the author's personal preferences, and the norms governing the given text type. The English language, on the other hand, prefers to signal logical relations by explicit grammatical devices (Baker 1992, 192).

In half of the cases (10 texts), the number of conjunctions remains the same in the target texts, even if this means that a zero conjunction is used (in five cases). Even in cases where the translation process generates changes in the number of conjunctions, the difference materializes in merely one inserted or omitted conjunction: $5-5$ such instances may be identified in each direction. There are three cases where the translator inserts new conjunctions (not used in the Hungarian source text) into the target text, but the opposite occurs in the same number of cases, where the translator omits a connective present in the Hungarian source text. Therefore, it may be argued that the results from the corpus are symmetrical in quantity; in terms of the use of conjunctions, there is no apparent tendency for either explicitation, or implicitation.

\subsubsection{Results of the detailed analysis of optional shifts}

Contrary to the claims made in the previous sub-section, the corpus does contain instances of optional shifts that result in explicitation (e.g., texts 01, 05, 08, and 09). In text 01, for instance, the translator cuts a sentence into two. In the Hungarian text, the two clauses are connected by the coordinating conjunction és (lit.: 'and'), which is changed (made more explicit) by the translator by inserting the clausal connective therefore, possibly to make understanding easier for foreign readers not entirely familiar with Hungarian foreign and internal policy (9).

(9) Optional shift resulting in explicitation (by change of conjunction)

Hungarian source text 01 :

4. A legnagyobb magyarországi ellenzéki párt, a Fidesz felkarolta a székelyföldi autonómia ügyét és Tőkés László püspök mellé állt, aki 1989 decemberében kulcsszerepet játszott a Ceausescu-rendszer megdöntésében, most pedig az RMDSZ alternatív szervezeteként létrejött Erdélyi Magyar Nemzeti Tanács (EMNT) élén az autonómia-törekvések fö szószólója.
English target text 01:

4a. Hungary's largest opposition party, Fidesz, has embraced the issue of autonomy for the Székely region. 4b. They therefore stand by Reformed Bishop László Tókés, who played a key role in toppling the Ceauşescu regime in December 1989 and currently acts as the principal spokesperson for the autonomy initiative as head of the Transylvanian Hungarian National Council, an NGO formed as an alternative to the DAHR. 
In text 05 , the implicit contrast in the Hungarian text is made explicit by the translator by inserting the connective however (text 05, sentence 6; example (10)):

(10) Optional shift resulting in explicitation (by making implicit logical relation explicit)

Hungarian source text 05:

English target text 05:

5. Elemzők, az orosz és a nemzetközi sajtó egy része azonban kétkedéssel fogadta a bejelentést, s kételyei vannak az államcsoportosulásnak a nyilvánosság előtt kinyilvánított politikai céljaival szemben is.

5. However, analysts and some members of the Russian and international press expressed doubts as regards the declaration, as well as voiced misgivings concerning the publicly declared political goals of the interstatealliance.

6. Bizonyos, hogy a néhány esztendeje még lassan kimúló geopolitikai kuriózumként elkönyvelt államszövetség a grúziai és az ukrajnai politikai fordulat után fontos szerepet játszik az Európától a Kaukázuson keresztül Ázsiáig terjedő térségben.

6. It is true however that the interstate-alliance - construed a few years ago as a slowly dying geopolitical curiosity - has been playing an important role in the region, extending from Europe, through the Caucasus to Asia, following the Georgian and Ukrainian political transformation.

In text 17, on the other hand, an optional, qualitative shift appears (the type of the cohesive device changes): the Hungarian text expresses causal relation by using demonstrative reference, which is translated into English by a causal connective (thus in (11)).

(11) Optional, qualitative shift (by changing the type of cohesive device used)

Hungarian source text 17:

English target text 17:

2. Dmitrij Medvegyev ezzel Oroszország modernkori történetének harmadik elnökévé vált.

2. Thus, Dmitry Medvedev became the third president in the history of Russia.

The following examples demonstrate cases where the translator decides to omit a conjunction. In text 02 , the translators omits the conjunction Ennek eredményeként 'As a result' explicitating an evident logical relation that can be inferred from the contents of the clauses (i.e., the context) (text 02 , sentence 3 in (12)): 
(12) Optional shift (by omitting the conjunction)

Hungarian source text 02:

English target text 02:

2. Az elfogadott - de ki nem hirdetett, azaz érvényben nem lévő - törvényt a kihirdetésre hivatott köztársasági elnök előzetes alkotmányossági vizsgálat tárgyává tette.

3. Ennek eredményeként az Alkotmánybíróság megállapította a jogszabály Szász Károlyt és helyetteseit elmozdító rendelkezésének alkotmányel2. Empowered with signing and publishing the Act, the President of the Republic instead referred the legislation, having been adopted but not yet signed and therefore not yet in force, to the Constitutional Court for preliminary constitutional review.

3. $\emptyset$ The Constitutional Court declared the clauses regulating the removal of Mr Károly Szász and his deputies lenességét. unconstitutional.

A similar case appears in text 15 , where the coordinating conjunction másfeloll 'on the other hand' is omitted by the translator. In text 16, the same logical relation is expressed by pedig 'as for', which does not occur in the English translation (13). A possible translation of this expression might be by using the as for structure, but the resulting clause (The other question is...) would become cumbersome. The expression másik kérdés 'the other question' includes - implicitly - the concept of a list, which makes pedig semantically redundant. The Hungarian version tolerates this, but in the English text the translator decides to omit it.

(13) Optional shift (by omitting a semantically redundant conjunction)

Hungarian source text 16 :

4. A másik kérdés pedig az, hogy Putyin elnöknek, illetve tábornokainak valóban a rakétavédelmi rendszer telepítésének közelsége okoz-e gondot, vagy az egész ügyet egy sokkal összetettebb játszma elemévé akarják fejleszteni, melyet egy esetleges egyezkedés során jó cserealapként lehet használni.
English target text 16:

4. The other question is whether the close vicinity of the deployment of the missile defence system is the real concern of President Putin and his generals, or the whole issue would be just an inflated component of a much larger scheme, which could serve as an effective bargaining chip in a future deal.

Another qualitative, optional shift appears in text 07 (14). The logical relation is apparent in both versions of the text, but is realised by a different device: ezzel szemben 'in contrast'; sentence 4, text $07 \mathrm{H}$ ) vs. While (sentence 3, text 07E). The translator combines the two sentences to form a long, complex sentence. Thus, in the English version the conjunction (While) establishes a link between the clauses of one single sentence, as 
opposed to lining two separate sentences, as is done in the Hungarian original.

(14) Optional shift (by combining two sentences)

Hungarian source text 07 :

English target text 07:

3. Legutóbb Mádl Ferenc köztársasági elnök 2005. július 1-i vatikáni búcsúlátogatásán került szóba a szlovákiai magyar püspök, az erdélyi érseki tartomány kialakítása, valamint a csángók anyanyelvi vallásgyakorlásának kérdése.

3. While issues such as the appointment of a Hungarian bishop in Slovakia, the establishment of an ecclesiastical province in Transylvania and the religious practices of the Csangos in their mother-tongue were last raised during President Ferenc Mádl's farewell visit to the Holy See on 1st July, 2005,

4. A 2005. szeptember 13-i magyar4. the future of Europe and matters reszentszéki külügyminiszteri találkozó lated to the financing of the Church in napirendjén ezzel szemben fóként Euró- Hungary dominated the agenda of the pa jövője és a magyarországi egyházfi- Hungarian-Vatican foreign ministerial nanszírozási kérdések szerepeltek.

talks on 13th September 2005.

In text 13, the English text expands the content of the conjunction Ennek értelmében 'in terms of this' and makes it more explicit by the insertion of a lexical element (In terms of the agreement; see (15)):

(15) Optional shift (by inserting a lexical element)

Hungarian source text 13:

2. A lépést november 22-én

Moszkvában - Vlagyimir Putyin orosz elnök és Romano Prodi olasz miniszterelnök jelenlétében - konkrét megállapodás követte.

3. Ennek értelmében közös céget hoznak létre a 10 milliárd USD összköltségüre becsült és 2013-ra üzemszerü müködésre átadni tervezett gázvezeték megvalósíthatóságának tanulmányozására.
English target text 13:

2. The step was followed by a concrete agreement signed in Moscow on the 22nd of November in the presence of Russian President Vladimir Putin and Italian Prime Minister Romano Prodi.

3. In terms of the agreement, a joint company would be established to carry out a comprehensive feasibility study with respect to the planned gas pipeline estimated to cost around 10 billion USD to be completed and rendered fully functional by 2013 .

Results of empirical investigations show that redundancy in a text depends largely on the text type and the author's expectations of the target readers' previous/background knowledge. Excessive explicitness in some cases leads to unnecessary verbosity (and thus encumbers identification of relevant information) instead of ensuring a necessary level of redundancy that would facilitate understanding of the text (for more details on this see Heltai 2005, 61-62). In their use of conjunction, the translations analysed tend to 
follow the source text closely: typically, there is no unnecessary redundancy (that is, the translator does not go into excess in making logical relations explicit). This is probably due to the fact that the intended readership of the news stories of the corpus (foreigners living within and beyond the borders of Hungary) are generally familiar with the matters at hand, therefore they do not need extra help in inferring logical relations.

\subsection{Lexical cohesion}

\subsubsection{Results of the qualitative analysis of shifts in lexical cohesion}

The qualitative comparison of the (re)creation of lexical cohesion in translation also shows shifts in some texts. The number of lexical cohesive devices is similar in almost all text pairs (except for texts $02,05,12,20$, where their number is identical), however, similarly to referential cohesion, their source and target language realisations differ in terms of

(a) the type of lexical cohesion applied (using a lexical unit from a different category than that of the source text unit, ${ }^{13}(16 \mathrm{a})$ ), or

(b) the position of the lexical cohesive unit (inserting a lexical unit where the source text used no such cohesive device; or omitting a lexical unit present in the source text).

There are examples in the corpus for both automatic shifts (generated by the systemic differences between the two languages), and optional shifts (which are the results of the translator's decisions (examples in $(16 \mathrm{~b}-\mathrm{c})$ ).

(16) Qualitative shifts of lexical cohesion ${ }^{14}$

a. other category:

Hungarian source text 03, sentence 4: English target text 03, sentence 4:

A miniszterelnök szándéka $(\mathrm{R})$ nem- The efforts $(\mathrm{S})$ of the prime minister csak visszatetszést szült a Szentszéknél, hanem vendéglátói rendre vissza is utasították felvetéseit, és határozott üzeneteket fogalmaztak evoked not only displeasure at the Holy See, but his hosts repeatedly rejected his suggestions, as well as meg a magyar kormány számára. expressed resolute messages for the Hungarian government.

13 There are no instances of referential substitution in the current corpus (see section 4.2.).

14 Abbreviations: $\mathrm{R}=$ repetition, $\mathrm{S}=$ synonymy, underlining $=$ shift, italics $=$ cohesive unit. 
b. insertion:

Hungarian source text 08 , sentence 9:

Bár Almunia visszafogott volt a lehetséges szankciók emlegetése során, ezek $\emptyset$ alkalmazására lehetőséget ad az Európai Közösségek 1164/94. számú, ún. kohéziós rendeletének 6 . pontja.

c. omission:

Hungarian source text 11, titlesentence 1:

Title: Magyarország a parlamenti választások után $\mathrm{Az}$ áprilisban megtartott kétfordulós parlamenti választásokon Magyarországon $(\mathrm{R})$ ismét a két kormánypárt, a Magyar Szocialista Párt (MSZP) és a Szabad Demokraták Szövetsége (SZDSZ) szerezte meg a kormányalakításhoz szükséges többséget az országgyülésben.
English target text 08, sentence 9: While Almunia showed restraint as regards the possible introduction of sanctions, Article 6 of the so-called cohesion regulation of the European Communities 1164/94 Act does provide for such measures $(\mathrm{R})$.

English target text 11, titlesentence 1:

Title: Hungary after the parliamentary elections At the two-round parliamentary elections in April $\underline{\emptyset}$, the two governing parties, the Hungarian Socialist Party (MSZP) and the Alliance of Free Democrats, once again won the majority of mandates needed to form a government.

In the text-by-text comparison of the data, the relevant translation universals were also examined. There are several examples in the corpus for the repetition avoidance hypothesis: in text 08 , for instance, previously discussed in section 4.2.1 (example (5)), where the translator omitted the target language version of the word Bizottság (lit.: 'Commission') mentioned several times in the preceding text. There are also various cases in the corpus where a lexical repetition in the source text is changed to a synonym or a co-hyponym in the target text; that is, verbatim repetition is avoided by inserting a lexical unit of a different category. Example (17) illustrates this phenomenon: the translator substitutes the source text repetition reformja-reformjára by a synonymous expression in the English target text reforms-process of reforming.

(17) Avoiding verbatim repetition (by a synonymous expression)

Hungarian source text 15 :

2. A növekedést azonban nem kísérte az ellátás reformja. [...]

4. Az egészségügyi ellátás reformjára

(R) ezért a források szükítésének idején kerül sor, ráadásul ez egyszerre több területen, drasztikus lépésekben, a 2006-os választási ígéreteknek ellentmondva és hiteltelen kormányzati kommunikációval övezve történik.
English target text 15:

2. However, this increase has not been accompanied by reforms. [...]

4. Hence, the process of reforming $(\mathrm{S})$ the health service is simultaneously taking place with the drastic tightening of resources in several spheres, which contravenes the 2006 election promises on the one hand, and is being communicated in an obscure manner by the government, on the other. 
However, there are numerous examples for the opposite too, where the translator uses

(a) verbatim repetition (e.g., military-military) instead of a synonym (as in the Hungarian original: katonai-harci, lit.: 'military-war/combat') or other lexical category used by the source text, or

(b) a lexical repetition is inserted in the target language where no such unit is used in the source text (e.g., text 20, sentence 20).

These are shown in (18):

(18) Using verbatim repetition (instead of a synonym, or zero)

Hungarian source text 20:

11. Az eddigi közvetett béketámogató tevékenységet a katonai müveletekben való aktív, közvetlen szerepvállalás egészíti ki.

12. 2008 végétől Magyarország Müveleti Tanácsadó és Összekötő Csoportot (OMLT - Operational Mentor and Liaison Team - OMLT) telepít Baghlan tartományba, Különleges Müveleti Csoportot (SOF - Special Operation Forces) küld Uruzganba, továbbá átveszi a kabuli nemzetközi repülőtér $\emptyset$ felügyeletét, 2009 nyarától kezdődően pedig újabb OMLT-t vezényel Uruzganba.

13. A közvetlen harci (S) feladatokban való részvétel azt vetíti elöre, hogy reális lehetőségként kell számolni magyar katonák halálával és az ennek nyomán elinduló belpolitikai vitákkal.
English target text 20:

11. The hitherto peace keeping operations will be complimented by active military participation.

12. As of the end of October 2008 , Hungary will deploy an Operational Mentor and Liaison Team (OMLT) to the province of Baghlan, dispatch Special Operation Forces (SOF) to Uruzgan and assume military $(\mathrm{R})$ supervision of Kabul international airport, as well as deploy another OMLT to Uruzgan from the summer of 2009.

13. Direct involvement in military $(\mathrm{R})$ tasks projects the death of Hungarian troops as a de facto reality and the consequent domestic dispute that would erupt in this regard.

In addition, the corpus also contains examples for cases where

(c) a referential unit is changed to a lexical cohesive device in the target language (19). 
(19) Using verbatim repetition (instead of reference)

Hungarian source text 13:

2. A lépést november 22-én Moszkvában - Vlagyimir Putyin orosz elnök és Romano Prodi olasz miniszterelnök jelenlétében - konkrét megállapodás követte.

3. Ennek értelmében közös céget hoznak létre a 10 milliárd USD összköltségüre becsült és 2013-ra üzemszerü működésre átadni tervezett gázvezeték megvalósíthatóságának tanulmányozására.
English target text 13:

2. The step was followed by a concrete agreement signed in Moscow on the 22nd of November in the presence of Russian President Vladimir Putin and Italian Prime Minister Romano Prodi.

3. In terms of the agreement, a joint company would be established to carry out a comprehensive feasibility study with respect to the planned gas pipeline estimated to cost around 10 billion USD to be completed and rendered fully functional by 2013 .

These findings harmonize with the results of the research conducted by Klaudy and Károly (2000), who analysed English-Hungarian news translation and found that professional translators - following the special characteristics of the genre - tend to use more verbatim repetitions than novice translators. The current data also corresponds to what Károly et al. (2000) found, who analysed English-Hungarian translations carried out for the purposes of language testing and concluded that high-rated translations included a higher frequency of lexical repetitions and were thus generally easier to comprehend than low-rated translations.

In sum, as regards the (re)creation of lexical cohesion in translation, the present corpus does not seem to verify the repetition avoidance hypothesis. Although there are cases where the translator avoids verbatim repetitions by using a lexical unit of a different category, in numerous other cases the exact opposite happens.

\subsubsection{Results of the analysis of optional shifts}

A relatively low number of optional shifts (83 in total) can be found in the corpus compared to the total number of lexical cohesive devices. This may be attributed to the stereotypical characteristics of the genre in question (the analytical news article; for details see 2.3.1), which encourages the translator to closely follow the original text. The in-depth analysis of optional shifts of lexical cohesion reveals the following main tendencies: 
(a) In the target text, the translator inserts information not appearing in the source text, that is, performs explicitation (e.g., what route the South Stream would traverse, In terms of the agreement, to the Constitutional $\overline{\text { Court for preliminary constitutional review, The planned South Stream gas }}$ pipeline and Hungary). However, this may not be viewed as evidence for the explicitation hypothesis, since there are numerous cases in the corpus where the translator omits source text information in the target language and thus, performs implicitation (e.g., as opposed to the $\emptyset$ [Hungarian] government, the "chosen successor" of $\underline{\emptyset}$ [President] Vladimir Putin).

(b) Nearly half of the optional shifts (altogether 40) appear in sentences carrying important discourse function (in the introduction, i.e., in the first or second sentence-21 cases; or in the closing sentence-19 cases). Although in several cases these shifts involve explicitation/explanation (e.g., (20a)), there are numerous examples for the opposite as well, where there is implicitation/omission taking place (e.g., (20b)).

(20) Shifts in sentences carrying important discourse function

a. Hungarian source text 02 :

English target text 02 :

2. Az elfogadott - de ki nem hirdetett, 2. Empowered with signing and pubazaz érvényben nem lévö - törvényt a lishing the Act, the President of the kihirdetésre hivatott köztársasági el- Republic instead referred the legisnök előzetes alkotmányossági vizsgálat lation, having been adopted but not tárgyává tette. yet signed and therefore not yet in force, to the Constitutional Court for preliminary constitutional review.

b. Hungarian source text 12 : English target text 12:

8. Az érdeklődés érthető: ismert készletei alapján Türkmenisztán a világ 34. legnagyobb földgázkészletével rendelkező országa, amelynek politikája nagy mértékben kihat a környezö országok, egyben az egész világ energiabiztonságára.

8. Their interest is understandable: in view of its known resources, Turkmenistan is the $3 \mathrm{rd}-4$ th largest $\emptyset$ in the world in terms of natural gas reserves and thus its political system to a large degree affects the neighbouring countries, as well as the energy security of the whole world.

(c) In terms of the event structure, optional shifts mainly appear in the "action" (47 cases) and "actors" components (29 cases), but occasionally also in the "setting" (6 cases) and the "commentary" components (1 case). No optional shifts were identified, however, in the components "attribution", "background" and "follow-up". Example (21) illustrates a case where the shift occurs in the "commentary". 
(21) Shift in event structure component ("commentary")

Hungarian source text 13 :

5. Az előkészületben lévő nagy európai gázvezeték-vállalkozásokkal - így például a projektcéggel és nyomvonallal évek óta rendelkező Nabuccóval - szemben például továbbra sem tudni, $\emptyset$ pontosan merre is halad majd és mely országok részesülnének a rajta szállított korlátozott gázmennyiségből.
English target text 13:

5. In contrast to the large European gas pipeline-projects under consideration, notably, the Nabucco, which established project-management companies and specified a defined route some time ago, it is still not known precisely as to what route the South Stream would traverse, or which countries would benefit from the limited gas supply it is designed to transport.

The shift in (21) is not motivated by the differences between the languages, but instead is the result of the translator's decision. Here the translator inserts the lexical unit South Stream in the target text where the source text includes no such expression; thus, explicitation is performed, making text comprehension easier for the reader.

The analysis of optional shifts revealed two cases of shifts in meaning. In both of these, the translator avoids verbatim repetition. In for instance Example 22, the repeated expression szerepvállalás (lit.: 'participation') is substituted for by contingent, modifying the original meaning of the text.

(22) Optional shift of lexical cohesion causing shift of meaning

Hungarian source text 20:

10. Az elkövetkező hónapokban a

NATO missziója keretében végzett afganisztáni magyar katonai szerepvállalás jellegében is jelentős változás következik be.
English target text 20:

10. There will be considerable qualitative changes in the role of the NATO-

bound Hungarian military contingent in Afghanistan in the next few months.

In sum, we may conclude that in view of the lexical cohesive devices, the current corpus does not provide evidence for either the repetition avoidance hypothesis, or the explicitation hypothesis. Although both phenomena are featured in the texts, numerous counter-examples have also been identified. As for optional shifts of lexical cohesion, it needs to be noted that although these shifts often make a given text segment more explicit (by explaining it and thus facilitating comprehension for the reader), there are also several cases where, quite the opposite happens: implicitation is performed by the omission of certain information originally included in the source text. Interestingly, there seems to be no significant difference between the two sub-corpora when comparing shifts appearing in sentences carrying important discourse function and shifts appearing in particular 
components of the event structure. On the other hand, in two cases, optional shifts cause a shift in meaning, too: although the translated texts do not differ considerably from the source texts, the meaning of the text does change to a certain degree.

\section{Conclusion}

This paper investigated the (re)creation of cohesion in Hungarian-English news translation. Based on the quantitative and qualitative analysis of the corpus, the following claim may be formulated regarding this language pair and form of translation: although certain shifts of cohesion do appear in translation, the difference - purely quantitatively - between the source and target texts bears no statistical significance. The in-depth, qualitative analysis of the data, on the other hand, has produced interesting results: it has shown that all cohesive shifts are qualitative (rather than quantitative) in nature (except for substitution and ellipsis, in which cases, the current corpus did not produce sufficient data to be able to judge). In the target language realisations of cohesive devices, the translated texts typically follow the source texts closely (there is no significant increase or decrease in the number of cohesive devices), however, there are qualitative differences in the cohesive ties used: their type or position in the translation tend to change.

The study also explored certain hypotheses related to particular tendencies regarded as universals of translation to contribute to the line of research testing the validity of these hypotheses. Generally speaking, the corpus does not provide evidence for the explicitation hypothesis. On the other hand, the in-depth analysis of the optional shifts of cohesion shows a marked tendency for explicitation, especially in the target language realisation of reference and lexical cohesion (they typically make the translations more specific). The corpus also fails to justify the other relevant translation universal, the repetition avoidance hypothesis. However, an interesting outcome of the investigation is that optional shifts of cohesion (particularly those of lexical cohesion) occur dominantly in key components of the event structure of the news stories and therefore affect/modify the contents and thus the message of the news text. It needs to be noted though that due to its descriptive and exploratory nature, this study does not deal with a very important question, namely, how the findings relate to reader appeal. To gain an even deeper understanding of the translational behaviour of cohesion, an important task of future research is to compare the results 
of text analysis with subjective/intuitive reader judgment of text quality and the message communicated.

Finally, the data suggest that there is a strong correlation between translational shifts and the systemic differences between the languages in question, moreover, translational shifts and the characteristics of the translation type (news translation) and the genre analysed (the analytical news article). The size of the corpus does not allow for drawing generalizable conclusions. Still, the findings bring new insights for at least three main areas of study. They contribute to discourse analysis in general and cohesion research in particular by showing that Halliday and Hasan's framework of analysis combined with another, discourse structural analysis (relevant from the point of view of the genre investigated) contributes to the genrebased study of translation as text, as it offers a better understanding of the way in which cohesion unfolds in translation. The study also brings new insights for research focusing on news translation. Applying Bell's framework for the description of the generic structure of the news texts provided valuable means for the description of how functional equivalence is reached (or violated!) in this corpus of content-focused texts, which have been claimed to require "invariance in transfer of their content" (Reiss 2000, 30).

\section{References}

Anderson, Stephen R. 1992. A-Morphous morphology. Cambridge: Cambridge University Press.

Baker, Mona. 1992. In other words. London: Routledge.

Baker, Mona. 1993. Corpus linguistics and translation studies. Implications and applications. In M. Baker, G. Francis and E. Rognini-Bonelli (eds.) Text and technology. Amsterdam \& Philadelphia: John Benjamins. 233-243.

Bakker, Matthijs, Koster Cees and Kitty van Leuven-Zwart. 1998. Shifts of translation. In M. Baker (ed.) Routledge encyclopedia of translation studies. London: Routledge. 226-231.

Beaugrande, Robert-Alain de and Wolfgang U. Dressler. 1981. Introduction to text linguistics. London \& New York: Longman.

Becher, Viktor. 2011a. Explicitation and implicitation in translation. A corpus-based study of English-German and German-English translations of business texts. Doctoral dissertation. Universität Hamburg.

Becher, Viktor. 2011b. When and why do translators add connectives? A corpus-based study. Target 23. 26-47.

Bell, Allan. 1991. The language of news media. Oxford \& Cambridge MA: Blackwell.

Bell, Allan. 1998. The discourse structure of news stories. In A. Bell and P. Garrett (eds.) Approaches to media discourse. Oxford \& Cambridge MA: Blackwell. 64-104.

Bielsa, Esperança. 2007. Translation in global news agencies. Target 19. 135-155.

Acta Linguistica Hungarica 60, 2013 
Bielsa, Esperança and Susan Bassnett. 2009. Translation in global news. Routledge: London.

Blum-Kulka, Shoshana. 1986. Shifts of cohesion and coherence in translation. In House \& Blum-Kulka (1986, 17-35).

Di Sciullo, Anna Maria and Edwin Williams. 1987. On the definition of word (Linguistic Inquiry Monograph 14). Cambridge MA: MIT Press.

Dijk, Teun Adrianus van. 1988. News as discourse. Hillsdale, NJ: Lawrence Erlbaum.

É. Kiss, Katalin, Ferenc Kiefer and Péter Siptár (eds.). 1998. Új magyar nyelvtan [A new Hungarian grammar]. Budapest: Osiris Kiadó.

Englund Dimitrova, Bielsa. 2005. Expertise and explicitation in the translation process. Amsterdam \& Philadelphia: John Benjamins.

Enkvist, Nils Erik. 1990. Seven problems in the study of coherence and interpretability. In U. Connor and A. M. Johns (eds.) Coherence in writing: Research and pedagogical perspectives. Washington, DC: TESOL. 9-2.

Fawcett, Peter. 1997. Translation and language. Linguistic theories explained. Manchester: St. Jerome.

Gottlieb, Henrik. 2010. Multilingual translation vs. English-fits-all in South African media. Across Languages and Cultures 11. 189-216.

Grabe, William and Robert B. Kaplan. 1996. Theory and practice of writing. Harlow: Addison Wesley Longman.

Gutwinski, Waldemar. 1976. Cohesion in literary texts: A study of some grammatical and lexical features of english discourse. The Hague: Mouton.

Halle, Morris. 1973. Prolegomena to a theory of word-formation. Linguistic Inquiry 4. $3-16$.

Halliday, Michael Alexander Kirkwood. 1985. An introduction to functional grammar. London: Edward Arnold.

Halliday, Michael Alexander Kirkwood and Ruqaiya Hasan. 1976. Cohesion in English. London: Longman.

Halliday, Michael Alexander Kirkwood and Christian M. I. M. Matthiessen. 2004. An introduction to functional grammar (Third edition). London: Hodder Arnold.

Hardy, Donald E. and Amy Leuchtmann. 1996. Topic versus cohesion in the prediction of causal ordering in English conversation. Discourse Processes 21. 237-254.

Hasan, Ruqaiya. 1984. Coherence and cohesive harmony. In J. Flood (ed.) Understanding reading comprehension. Delaware: International Reading Association. 181-219.

Heltai, Pál. 2003. Az explicitáció egyes kérdései angol-magyar szakfordításban [Particular questions of explicitation in English-Hungarian translation]. In M. Feketéné Silye (ed.) Porta lingua: Szaknyelvoktatásunk az EU kapujában [Teaching English for specific purposes in Hungary before entering the EU]. Debrecen: DE ATC. 173-198.

Heltai, Pál. 2005. Explicitation, redundancy, ellipsis and translation. In Károly \& Foris (2005, 45-74).

Heltai, Pál and Gabriella Juhász. 2002. A névmások fordításának kérdései angol-magyar és magyar-angol fordításokban [Questions of translating pronouns in EnglishHungarian and Hungarian-English translations]. Fordítástudomány 4. 46-62.

Hoey, Michael. 1991. Patterns of lexis in text. Oxford: Oxford University Press.

Acta Linguistica Hungarica 60, 2013 
Holland, Robert. 2006. Language(s) in the global news: Translation, audience design and discourse (mis)interpretation. Target 18. 229-259.

House, Juliane and Shoshana Blum-Kulka (eds.). 1986. Interlingual and intercultural communication: Discourse and cognition in translation and second language acquisition studies. Tübingen: Günter Narr Verlag.

Jenei, Gabriella. 2006. A referencia fordításának kérdései angol-magyar és angol-spanyol fordításokban [Questions of translating reference in English-Hungarian and English-Spanish translation]. Fordítástudomány 8. 27-45.

Károly, Krisztina. 2002. Lexical repetition in text. Frankfurt am Main: Peter Lang.

Károly, Krisztina. 2007. Szövegtan és fordítás [Text studies and translation]. Budapest: Akadémiai Kiadó.

Károly, Krisztina. 2010. Az ismétlésről a fordítási univerzálék tükrében. Lexikai ismétléseltolódások a magyar-angol fordításban [On repetition from the point of view of the universals of translation. Shifts of lexical repetition in Hungarian-English translation]. Magyar Nyelv 106. 322-338.

Károly, Krisztina and Ágota Fóris (eds.). 2005. New trends in translation studies. Budapest: Akadémiai Kiadó.

Károly, Krisztina, Anette Árvay, Melinda Edwards, Hajnal Fekete, Katalin Kolláth and Gyula Tankó. 2000. A szövegkohézió mérése a vizsgafordítások értékelésében [Measuring textual cohesion in the assessment of translation for testing purposes]. Fordítástudomány 2. 36-63.

Klaudy, Kinga. 1987. Fordítás és aktuális tagolás [Translation and thematic structure] (Nyelvtudományi Értekezések 123). Budapest: Akadémiai Kiadó.

Klaudy, Kinga. 2003. Languages in translation. Lectures on the theory, teaching and practice of translation - with illustrations in English, Russian and Hungarian. Budapest: Scholastica.

Klaudy, Kinga. 2006. Szövegszintű müveletek a fordításban [Text-level operations in translation]. In L. Galgóczy and L. Vass (eds.) A mondat kaland. Hetven tanulmány Békési Imre 70. születésnapjára [The sentence is an adventure. Seventy papers for Imre Békési's 70th birthday]. Szeged: JGyTF Kiadó. 204-211.

Klaudy, Kinga and Krisztina Károly. 2000. The text-organizing function of lexical repetition in translation. In M. Olohan (ed.) Intercultural faultlines. Research models in translation studies I: Textual and cognitive aspects. Manchester: St. Jerome. $143-160$.

Klaudy, Kinga and Krisztina Károly. 2005. Implicitation in translation: Empirical evidence for operational asymmetry in translation. Across Languages and Cultures 6. $13-28$.

Kocsány, Piroska. 1995. Műhelytanulmány az “o”” névmásról [On the pronoun ő]. Magyar Nyelvőr 119. 285-293.

Limon, David. 2004. Translating news genres between Slovene and English: An analytical framework. Across Languages and Cultures 5. 43-65.

Makkos, Anikó. 2010. Szöveggrammatikai eszközök fordítása és alkalmazása nyelvvizsgázók fordításaiban [The translation and application of the tools of text grammar in the translations of language test takers]. Fordítástudomány 12. 96-121.

Neubert, Albrecht and Gregory M. Shreve. 1992. Translation as text. Kent State University Press: Kent, OH. 
Pléh, Csaba. 1998. A mondatmegértés a magyar nyelvben [Sentence interpretation in Hungarian]. Budapest: Osiris Kiadó.

Polo, Javier Fernandez. 1992. Some discoursal aspects in the translation of popular science texts from English into Spanish. In Wårwik et al. (1992, 257-264).

Pym, Anthony. 2005. Explaining explicitation. In Károly \& Foris (2005, 29-43).

Reiss, Katarina. 2000. Translation criticism - The potentials and limitations. Manchester: St. Jerome.

Rogers, Margaret. 1997. Synonymy and equivalence in special-language texts. In A. Trosborg (ed.) Text typology and translation. Amsterdam \& Philadelphia: John Benjamins. 217-246.

Sanders, Ted, Wilbert Spooren and Leo Noordman. 1992. Toward a taxonomy of coherence relations. Discourse Processes 15. 1-35.

Shlesinger, Miriam. 1995. Shifts in cohesion in simultaneous interpreting. The Translator 1. $193-214$.

Svindland, Arne S. 1992. Originals and translations. The case of coordinatio. In Wårwik et al. $(1992,509-5)$.

Szikszainé Nagy, Irma. 1999. Leíró magyar szövegtan [Descriptive Hungarian text linguistics]. Budapest: Osiris Kiadó.

Tolcsvai Nagy, Gábor. 2001. A magyar nyelv szövegtana [A text linguistics of Hungarian]. Budapest: Nemzeti Tankönyvkiadó.

Toury, Gideon. 1980. In search of a theory of translation. Tel Aviv: The Porter Institute for Poetics and Semiotics, Tel Aviv University.

Toury, Gideon. 1986. Monitoring discourse transfer: A test-case for a developmental model of translatio. In House \& Blum-Kulka (1986, 79-95).

Törkenczy, Miklós. 1997. Hungarian verbs and essentials of grammar. A practical guide to the essentials of Hungarian. Budapest: Corvina.

Valdeón, Roberto A. 2005. The "translated" Spanish service of the BBC. Across Languages and Cultures 6. 195-220.

Vehmas-Lehto, Inkeri. 1989. Quasi-correctness. A critical study of Finnish translations of Russian journalistic texts. Helsinki: Neuvostoliittoinstituuti.

Vinay, Jean-Paul and Jean Darbelnet. 1995. Comparative stylistics of French and English. A methodology for translation. Amsterdam \& Philadelphia: John Benjamins.

Wårwik, Brita, Sanna-Kaisa Tanskanen and Risto Hiltunen (eds.). 1992. Organization in discourse. Proceedings from the Turku conference (Anglicana Turkuensia 14). Turku: University of Turku. 


\section{Appendix}

Details of lexical cohesion analysis related to the first two sentences of Text 16

\begin{tabular}{|c|c|c|c|}
\hline 16H S.No. & Cohesive device & Type & Antecedent (S.No.) \\
\hline$(1)$ & amerikai & REP & $\overline{a m e r i k a i}(0)$ \\
\hline$(1)$ & telepítéséröl & REP & telepítése $(0)$ \\
\hline (1) & telepítésének & REP & telepitése $(0)$ \\
\hline$(2)$ & Európában & REP & Európában (1) \\
\hline$\overline{(2)}$ & amerikai & REP & amerikai $(1)$ \\
\hline$(1)$ & radarállomás & MER & rakétavédelmi rendszer (0) \\
\hline (1) & védelmi ... eszköz & MER & rakétavédelmi rendszer $(0)$ \\
\hline$(2)$ & Moszkvából & MER & Oroszországban (1) \\
\hline$(2)$ & Európában & MER & Csehország (1) \\
\hline$(2)$ & Európában & MER & Lengyelország (1) \\
\hline$(2)$ & orosz & $\mathrm{HIPO}$ & amerikai (1) \\
\hline
\end{tabular}

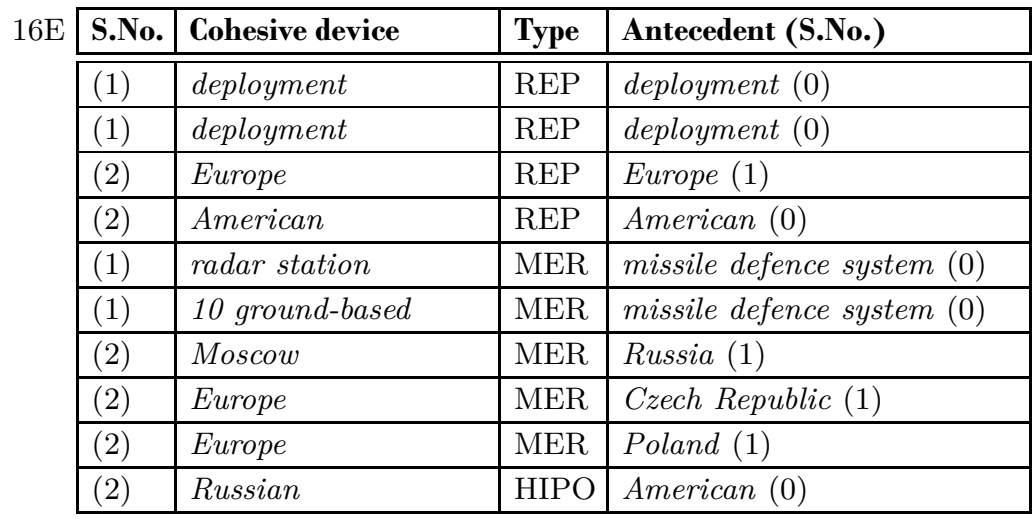

Abbreviations: $\mathrm{H}=$ Hungarian text; $\mathrm{E}=$ English translation; S.No. $=$ number of sentence containing the cohesive tie; $\mathrm{REP}=$ repetition, MER = meronymy, HIPO = hyponymy. 